\title{
DTX2 Gene
}

National Cancer Institute

\section{Source}

National Cancer Institute. DTX2 Gene. NCI Thesaurus. Code C106465.

This gene plays a role in regulation of cell-cell communication. 